Jurnal Abdidas Volume 2 Nomor 5 Tahun 2021 Halaman 1197 - 1203

JURNAL ABDIDAS

http://abdidas.org/index.php/abdidas

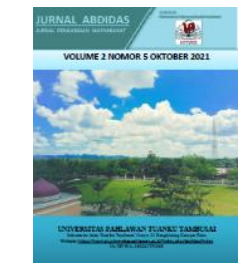

\title{
Pemanfaatan Video dan Media Sosial sebagai Sarana Edukasi Protokol Kesehatan di Masa Pandemi Covid-19
}

\author{
Ika Rahayu Satyaninrum ${ }^{1}$, Ade Lestari ${ }^{2}$, Zumaida Awalia ${ }^{3}$, Lili Hayati ${ }^{4}$, Ayu Yunita Jamil ${ }^{5}$ \\ Pendidikan Islam Anak Usia Dini, STAI Al-Hamidiyah Jakarta, Indonesia ${ }^{1}$ \\ Pendidikan Agama Islam, STAI Al-Hamidiyah Jakarta, Indonesia ${ }^{2,3,4,5}$ \\ Email : ikarahayu@staialhamidiyahjkt.ac.id ${ }^{1}$ adele.adelestari99@ gmail.com ${ }^{2}$ \\ zumaidaawalia@gmail.com ${ }^{3}$ rr9683629@gmail.com ${ }^{4}$ ayuyunitaaj12@gmail.com ${ }^{5}$
}

\begin{abstract}
Abstrak
World Health Organization (WHO) sebagai otoritas Kesehatan dunia memberikan status darurat kesehatan masyarakat akibat merebaknya virus Covid-19. Di Indonesia baik pemerintah pusat maupun pemerintah daerah membuat sejumlah aturan untuk menangani Covid-19, adapun masyarakat memiliki peran penting dalam memutus mata rantai penularan virus Covid-19 agar tidak menimbulkan sumber penularan baru. Pendekatan pada masyarakat dilakukan dengan cara-cara persuasif yaitu dengan menempatkan masyarakat sebagai subjeknya. Sasaran pada kegiatan ini adalah warga RW.06 Kelurahan Rangkapan Jaya Baru. Metode kegiatan terdiri dari pembuatan media edukasi, edukasi masyarakat melalui video, pembagian paket protokol kesehatan, pengadaan tempat cuci tangan, dan seminar online. Kegiatan diawali dengan proses pembuatan video, kemudian menyebarkan video tersebut kepada masyarakat melalui media sosial, pembagian paket protokol kesehatan, pengadaan tempat cuci tangan di lingkungan, dan mengadakan seminar online. Kegiatan yang terakhir adalah melakukan evaluasi. Evaluasi dilakukan dengan cara melakukan pengamatan kepada warga sekitar tentang kepatuhan menggunakan masker sekaligus membagikan masker dan handsanitizer kepada warga sekitar dan melihat efektivitas penggunaan hand washer di ruang publik.Kegiatan ini berjalan dengan baik dan lancar, antusias warga dalam mendukung kegiatan ini juga sangat baik.
\end{abstract} Kata kunci: video, media sosial, edukasi, protokol kesehatan, Covid-19

\begin{abstract}
The World Health Organization/WHO as the authority of the world health has declared a public health emergency status for the outbreak of the Covid-19 virus. In Indonesia, both the central government and regional governments make a number of rules to deal with Covid-19, while the community has an important role in breaking the chain of transmission of the Covid-19 virus so as not to cause new sources of transmission. The approach to the community is carried out in persuasive ways, namely by placing the community as the subject. The target of this activity is the residents of RW.06 Rangkapan Jaya Baru Village. The method of activity consists of making educational media, educating the public through videos, distributing health protocol packages, providing hand washing facilities, and online seminars. The activity began with the process of making a video, then distributing the video to the public through social media, distributing health protocol packages, washing hands in the environment, and holding online seminars. The last activity is evaluating. The evaluation was carried out by observing local residents about compliance with using masks as well as distributing masks and hand sanitizers to local residents and seeing the effectiveness of using hand washers in public spaces. This activity went well and smoothly, the enthusiasm of the residents in supporting this activity was also very good.
\end{abstract}

Keywords: video, social media, health protocol, Covid-19

Copyright (c) 2021 Ika Rahayu Satyaninrum, Ade Lestari, Zumaida Awalia, Lili Hayati, Ayu Yunita Jamil $\triangle$ Corresponding author

Address : Jl. Raya Depok Sawangan Km.2 No.12, Jawa Barat

Email : ikarahayu@staialhamidiyahjkt.ac.id

DOI : https://doi.org/10.31004/abdidas.v2i5.433

ISSN 2721- 9224 (Media Cetak)

ISSN 2721- 9216 (Media Online) 
1198 Pemanfaatan Video dan Media Sosial sebagai Sarana Edukasi Protokol Kesehatan di Masa Pandemi Covid-19 - Ika Rahayu Satyaninrum, Ade Lestari, Zumaida Awalia, Lili Hayati, Ayu Yunita Jamil DOI: https://doi.org/10.31004/abdidas.v2i5.433

\section{PENDAHULUAN}

Pada bulan Desember 2019 di Wuhan, Cina terdeteksi kasus penyakit pernafasan akut yang muncul tanpa diketahui secara pasti penyebabnya (Hult Khazaie \& Khan, 2020). Kasus ini meningkat pesat dan tidak sampai satu bulan penyakit ini telah menyebar di berbagai provinsi lainnya di Cina dan merambah ke negara lainnya seperti Thailand, Jepang dan Korea Selatan (Huang et al., 2020). Kemudian pada 11 Februari 2020 World Health Organization (WHO) sebagai otoritas kesehatan dunia mengumumkan nama penyakit tersebut yaitu Coronavirus Disease (Covid-19) yang disebabkan oleh virus Severe Acute Respiratory Syndrome Coronavirus-2 (SARS-CoV-2) (World Health Organization, 2020). Virus menyebar dengan cepat ke seluruh dunia, pemimpin WHO mengumumkan wabah tersebut sebagai sebuah pandemik pada tanggal 11 Maret 2020. Saat ini penyebaran virus SARSCoV-2 dari manusia ke manusia menjadi sumber transmisi utama yaitu melalui droplet yang keluar saat batuk atau bersin (Han Y, Yang H., 2020). Kasus Covid-19 di Indonesia sendiri pertama kali muncul pada awal bulan Maret 2020 dan per tanggal 15 April 2021 menunjukan 1.589.859 orang di Indonesia terpapar Covid.19 dengan 43.073 diantaranya wafat (S. C.-19 R. Indonesia, 2021).

Pada tanggal 31 Maret 2020 Presiden Republik Indonesia telah menandatangani Keputusan Presiden Nomor 11 Tahun 2020 tentang Penetapan Kedaruratan Kesehatan Masyarakat terkait Covid-19 (P. R. Indonesia, 2020). Dalam upaya mencegah penyebaran wabah virus Covid-19 pemerintah menerapkan berbagai kebijakan sebagai upaya memutus mata rantai penyebaran virus Covid-19, yang diatur melalui Surat Keputusan Menteri Kesehatan Republik Indonesia Nomor HK.01.07/MENKES/382/2020 tentang protokol kesehatan bagi masyarakat di tempat dan fasilitas umum dalam rangka pencegahan dan pengendalian corona virus disease 2019 (Covid-19).

Masyarakat memiliki peran penting dalam memutus mata rantai penularan virus Covid-19 agar tidak menimbulkan sumber penularan baru. Peran masyarakat untuk dapat memutus mata rantai penularan Covid-19 harus dilakukan dengan menerapkan protokol kesehatan sesuai dengan Keputusan Menteri Kesehatan Republik Indonesia Nomor HK.01.07/MENKES/382/2020, dimana kita harus mulai dari diri sendiri melalui Perlindungan Kesehatan Individu. Penularan Covid-19 terjadi melalui droplet yang dapat menginfeksi manusia dengan masuknya droplet tersebut ke dalam tubuh melalui hidung, mulut, dan mata. Prinsip pencegahannya adalah dengan menghindari masuknya virus tersebut melalui tindakan:

a. Menggunakan alat pelindung diri berupa masker yang menutupi hidung dan mulut hingga dagu.

b. Membersihkan tangan secara teratur dengan mencuci tangan pakai sabun dengan air mengalir atau menggunakan cairan antiseptik berbasis alkohol/ handsanitizer.

c. Menjaga jarak minimal 2 meter dengan orang lain untuk menghindari terkena droplet dari orang yang berbicara, batuk, bersin, serta 
1199 Pemanfaatan Video dan Media Sosial sebagai Sarana Edukasi Protokol Kesehatan di Masa Pandemi Covid-19 - Ika Rahayu Satyaninrum, Ade Lestari, Zumaida Awalia, Lili Hayati, Ayu Yunita Jamil DOI: https://doi.org/10.31004/abdidas.v2i5.433

menghindari kerumunan, keramaian, dan berdesakan.

d. Meningkatkan daya tahan tubuh dengan menerapkan Perilaku Hidup Bersih dan Sehat (PHBS).

Di kota Depok tempat dimana pengabdian masyarakat ini dilakukan, Wali Kota Depok telah membuat sejumlah peraturan untuk menangani Covid-19 yang terdiri dari 13 Peraturan Wali Kota, 43 Surat Keputusan, 8 Surat Edaran, dan 4 Instruksi Wali Kota. Pemerintah Kota Depok juga menstimulasi pada tingkat kecamatan dan kelurahan untuk menangani Covid-19, adapun pendekatan pada masyarakat dilakukan dengan cara-cara persuasif dengan menempatkan masyarakat sebagai subjeknya. Akan tetapi kenyataannya tingkat kepatuhan masyarakat dalam menerapkan aturan-aturan tersebut masih variatif, Walikota Depok mengungkapkan bahwa kesadaran warga Depok masih rendah apalagi pada RT-RT yang masuk zona hijau cenderung merasa aman, untuk itu perlu terus diingatkan agar tidak lalai dalam menjalankan protokol kesehatan (Tekan Laju Penularan COVID-19 Lewat Kesadaran Patuhi Protokol Kesehatan, 2021).

Dengan demikian perlu dilakukan edukasi secara masif utamanya melalui media sosial agar dapat menjangkau masyarakat yang lebih luas dari berbagai kalangan dan kelompok usia. Edukasi yang dilakukan adalah mengenai pentingnya penerapan 3M (Menggunakan Masker, Mencuci Tangan, dan Menjaga Jarak) sehingga masyarakat mampu menjaga kesehatan dan menjalankan program penanggulangan Covid-19 dari pemerintah yang pada akhirnya berdampak pada penekanan laju penularan Covid-19.

\section{METODE}

Kegiatan pengabdian masyarakat ini dilakukan mulai dari tanggal 27 Maret sampai dengan 1 Mei 2021 di Kota Depok dengan lokus pengabdian pada Kelurahan Rangkapan Jaya Baru. Kegiatan edukasi yang dilakukan adalah sebagai berikut:

1. Pembuatan media edukasi berupa video tentang pembuatan masker kain dari bahan sisa pakai dan pembuatan handsanitizer dengan harga ekonomis.

2. Edukasi yang dilakukan dengan cara demonstrasi yaitu mengajari peserta cara membuat masker, dan handsanitizer melalui video.

3. Pengemasan dan pembagian paket protokol kesehatan berupa masker dan handsanitizer bagi masyarakat di Kelurahan Rangkapan Jaya Baru, Kota Depok.

4. Pengadaan tempat cuci tangan di pusat aktivitas kemasyarakatan yang ditunjuk di lingkungan Kelurahan Rangkapan Jaya Baru, Kota Depok.

5. Membuat seminar online.

Berbagai kegiatan yang dilakukan ini disertai dengan sosialisasi kepada masyarakat dengan cara menyebarluaskan poster dan video melalui media sosial seperti WhatsApp, Instagram, Facebook, Twiter, Youtube dan sebagainya.

Kegiatan yang terakhir adalah melakukan evaluasi. Evaluasi dilakukan dengan cara melakukan pengamatan kepada warga sekitar tentang kepatuhan menggunakan masker sekaligus 
1200 Pemanfaatan Video dan Media Sosial sebagai Sarana Edukasi Protokol Kesehatan di Masa Pandemi Covid-19 - Ika Rahayu Satyaninrum, Ade Lestari, Zumaida Awalia, Lili Hayati, Ayu Yunita Jamil

DOI: https://doi.org/10.31004/abdidas.v2i5.433

membagikan masker dan handsanitizer kepada warga sekitar dan melihat efektivitas penggunaan hand washer di ruang publik.

\section{HASIL DAN PEMBAHASAN}

Pelaksanaan kegiatan pengabdian masyarakat ini dilakukan setelah dilakukan pengamatan terhadap kondisi penerapan protokol kesehatan di Kota Depok yang masih bervariatif tingkat kepatuhannya. Adapuan pelaksanaan kegiatan pengabdian masyarakat meliputi:

1. Pembuatan video edukasi.

Pembuatan video merupakan bentuk kegiatan pertama dalam kegiatan pengabdian masyarakat sebagai usaha untuk menyajikan edukasi tentang protokol kesehatan yang mudah diterima masyarakat.

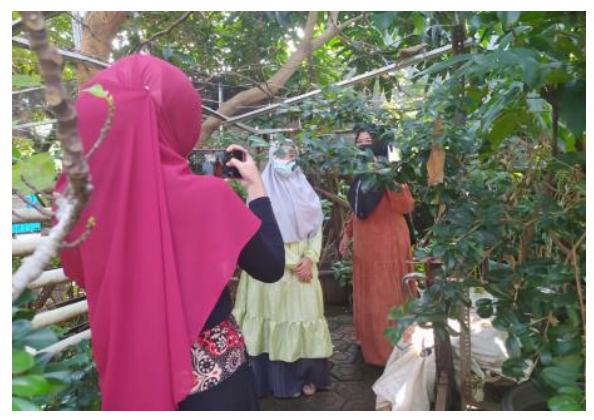

Gambar 1. Proses Pembuatan Video (sumber: Dok. Kelompok KKN)

2. Edukasi melalui video.

Video yang telah dibuat dan sudah melalui proses kelayakan tayang disebarluaskan melalui media sosial seperti WhatsApp, Instagram, Facebook, Twiter, Youtube dan sebagainya. Adapun video yang telah dibuat terbagi menjadi beberapa episode yaitu tutorial pembuatan masker kain, tutorial pembuatan handsanitizer, pentingnya menjaga jarak, pentingnya menjauhi kerumunan, pentingnya memakai masker, dan cara mencuci tangan.

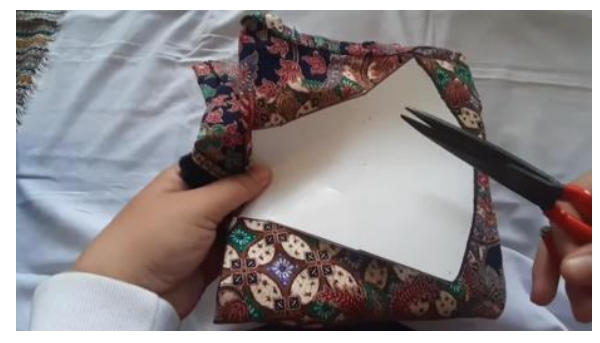

Gambar 2. Video Pembuatan Masker Kain (sumber: Dok. Kelompok KKN)

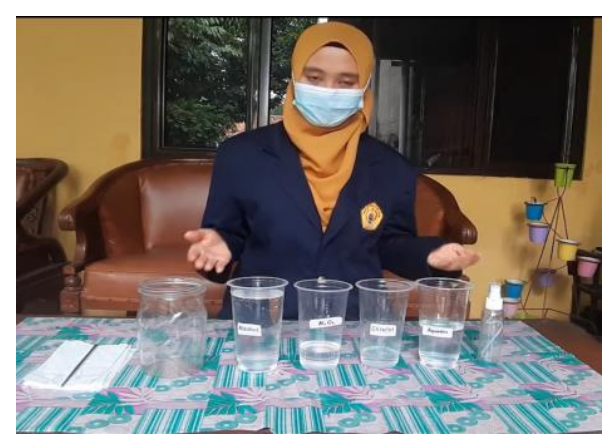

Gambar 3. Video Pembuatan Handsanitizer (sumber: Dok. Kelompok KKN)

3. Pengemasan dan pembagian paket protokol kesehatan berupa masker dan handsanitizer.

Cairan handsanitizer yang telah dibuat dalam jumlah banyak dikemas dalam botol dengan kapasitas 50ml. Setiap botol dilengkapi dengan label informasi tentang handsanitizer.

4. Pengadaan tempat cuci tangan (handwasher).

Bentuk kegiatan lainnya sebagai upaya untuk mengedukasi warga akan pentingnya pencegahan penyebaran Covid-19 adalah dengan pengadaan handwasher yang 
dilengkapi dengan sabun. handwasher ini diletakan di Masjid Al-Ihya, lingkungan RW.06 Kelurahan Rangkapan Jaya Baru, Kota Depok. Pada salah satu bagian handwasher terdapat informasi tata cara mencuci tangan yang benar. Diharapkan dengan adanya handwasher ini para warga dapat menjaga kebersihan tangan sebagai upaya untuk memutus penyebaran Covid-19.

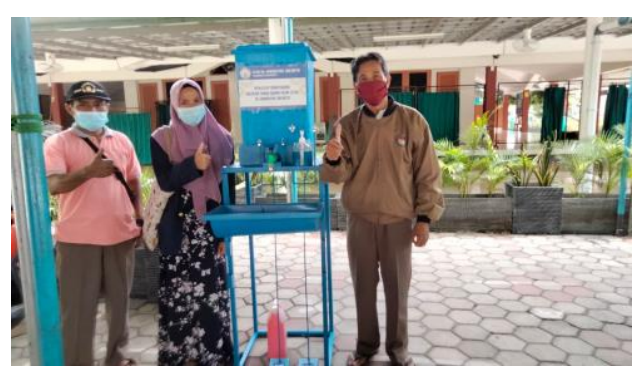

Gambar 4. Penempatan handwasher di Masjid AlIhya (sumber: Dok. Kelompok KKN)

5. Membuat seminar online.

Bentuk kegiatan terakhir dari pengabdian masyarakat ini adalah dengan mengadakan seminar online tentang pentingnya kesehatan mental di masa pandemi, dimana di dalam seminar tersebut juga disosialisasikan tentang pentingnya protokol kesehatan. Sehingga diharapkan masyarakat dapat lebih memahami dan menerapkannya dalam kehidupan seharihari. Dalam penyelenggaraannya, kegiatan seminar ini merupakan kolaborasi dari dua kelompok KKN.

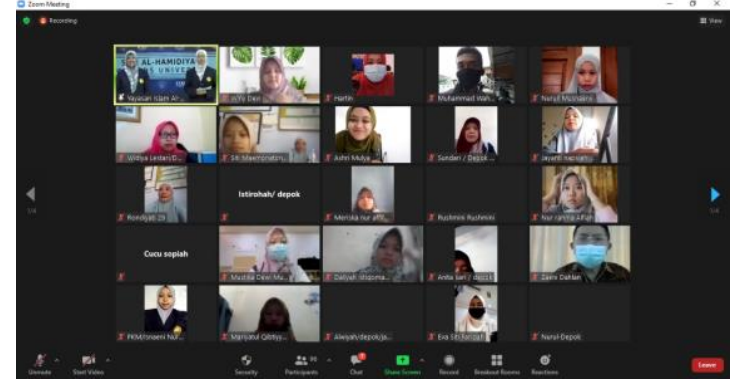

Gambar 5. Kegiatan Seminar Online (sumber: Dok. Kelompok KKN)

Kemudian pada kegiatan yang terakhir adalah melakukan evaluasi. Evaluasi dilakukan dengan cara melakukan pengamatan kepada warga sekitar tentang kepatuhan menggunakan masker sekaligus membagikan masker dan handsanitizer kepada warga sekitar dan melihat efektivitas penggunaan hand washer di ruang publik.

Adapun masker yang akan dibagikan merupakan masker yang dibuat sendiri dan dikemas dalam plastik agar tetap higienis. Handsanitizer dan masker ini kemudian dikemas dan dibagikan kepada warga. Pembagian handsanitizer dan masker ini sekaligus sebagai upaya evaluasi edukasi kepada warga tentang pentingnya menerapkan protokol kesehatan selama pandemi Covid-19, kegiatan ini disambut baik oleh warga.

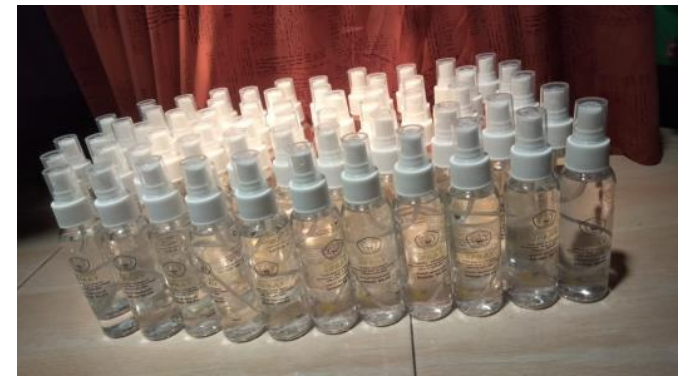

Gambar 6. Handsanitizer siap dibagikan (sumber: Dok. Kelompok KKN) 
1202 Pemanfaatan Video dan Media Sosial sebagai Sarana Edukasi Protokol Kesehatan di Masa Pandemi Covid-19 - Ika Rahayu Satyaninrum, Ade Lestari, Zumaida Awalia, Lili Hayati, Ayu Yunita Jamil DOI: https://doi.org/10.31004/abdidas.v2i5.433

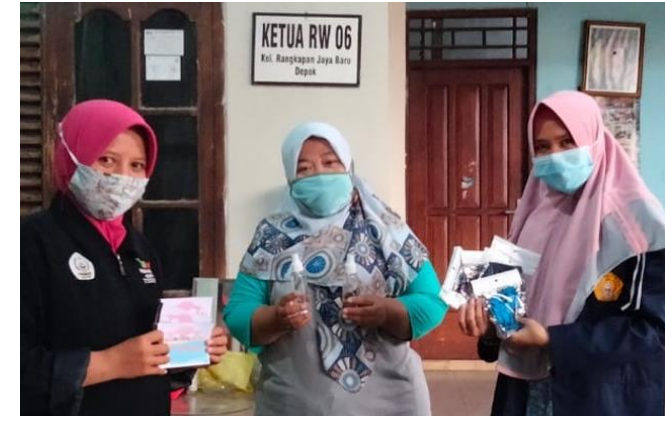

Gambar 7. Pembagian Paket Protokol Kesehatan (sumber: Dok. Kelompok KKN)

\section{SIMPULAN}

Berdasarkan uraian di atas dapat disimpulkan bahwa upaya untuk memutus mata rantai penyebaran Covid-19 merupakan tanggung jawab bersama antara pemerintah, masyarakat, pihak swasta, lembaga keagamaan, dan media. Program kegiatan untuk memberikan edukasi kepada masyarakat tentang pentingnya menerapkan protokol kesehatan harus dilakukan secara kontinu dan konsisten.

Dengan keterbatasan waktu yang dimiliki, kami menyadari bahwa belum sepenuhnya konsep dan metode edukasi penerapan protokol kesehatan dilakukan. Pada pengabdian berikutnya diharapkan dapat melakukan kegiatan yang lebih terarah dan komprehensif sehingga dapat menjangkau semua lini masyakarat agar tujuan mengedukasi warga dapat tercapai.

\section{UCAPAN TERIMA KASIH}

Terima kasih kami ucapkan kepada Koordinator Pengabdian Masyarakat STAI AlHamidiyah Jakarta, dan Kelurahan Rangkapan Jaya Baru khususnya warga RW.06 yang telah memberikan kesempatan untuk dapat melaksanakan program pengabdian kepada masyarakat ini. Ucapan terima kasih juga kami sampaikan kepada kelompok KKN Kelurahan Meruyung yang sudah berkolaborasi dan bekerjasama dengan kami.

\section{DAFTAR PUSTAKA}

Huang, C., Wang, Y., Li, X., Ren, L., Zhao, J., Hu, Y., Zhang, L., Fan, G., Xu, J., Gu, X., Cheng, Z., Yu, T., Xia, J., Wei, Y., Wu, W., Xie, X., Yin, W., Li, H., Liu, M., ... Cao, B. (2020). Clinical features of patients infected with 2019 novel coronavirus in Wuhan, China. The Lancet, 395(10223), 497-506. https://doi.org/10.1016/S01406736(20)30183-5

Hult Khazaie, D., \& Khan, S. S. (2020). Social psychology and pandemics: Exploring consensus about research priorities and strategies using the Delphi method. Asian Journal of Social Psychology, 23(4), 363371. https://doi.org/10.1111/ajsp.12442

Indonesia, P. R. (2020). Pembatasan Sosial Berskala Besar dalam Rangka Percepatan Penangan Covid-19. https://jdih.setkab.go.id/PUUdoc/176085/PP Nomor_21_Tahun_2020.pdf

Indonesia, S. C.-19 R. (2021). Peta Sebaran Covid-19 di Indonesia. https://covid19.go.id/peta-sebaran-covid19

Tekan Laju Penularan COVID-19 Lewat Kesadaran Patuhi Protokol Kesehatan. (2021).

World Health Organization. (2020). Naming the coronavirus disease (COVID-19) and the virus that causes it. Www.Who.Int. https://www.who.int/emergencies/diseases/no vel-coronavirus-2019/technicalguidance/naming-the-coronavirus-disease(covid-2019)-and-the-virus-that-causes-it

Huang, C., Wang, Y., Li, X., Ren, L., Zhao, J., Hu, Y., Zhang, L., Fan, G., Xu, J., Gu, X., Cheng, Z., Yu, T., Xia, J., Wei, Y., Wu, W., Xie, X., Yin, W., Li, H., Liu, M., ... Cao, B. (2020). Clinical features of patients infected with 
1203 Pemanfaatan Video dan Media Sosial sebagai Sarana Edukasi Protokol Kesehatan di Masa Pandemi Covid-19 - Ika Rahayu Satyaninrum, Ade Lestari, Zumaida Awalia, Lili Hayati, Ayu Yunita Jamil DOI: https://doi.org/10.31004/abdidas.v2i5.433

2019 novel coronavirus in Wuhan, China.

The Lancet, 395(10223), 497-506.

https://doi.org/10.1016/S0140-

6736(20)30183-5

Hult Khazaie, D., \& Khan, S. S. (2020). Social psychology and pandemics: Exploring consensus about research priorities and strategies using the Delphi method. Asian Journal of Social Psychology, 23(4), 363371. https://doi.org/10.1111/ajsp.12442

Indonesia, P. R. (2020). Pembatasan Sosial Berskala Besar dalam Rangka Percepatan Penangan Covid-19. https://jdih.setkab.go.id/PUUdoc/176085/PP_ Nomor_21_Tahun_2020.pdf

Indonesia, S. C.-19 R. (2021). Peta Sebaran Covid-19 di Indonesia. https://covid19.go.id/peta-sebaran-covid19

Tekan Laju Penularan COVID-19 Lewat Kesadaran Patuhi Protokol Kesehatan. (2021).

World Health Organization. (2020). Naming the coronavirus disease (COVID-19) and the virus that causes it. Www.Who.Int. https://www.who.int/emergencies/diseases/no vel-coronavirus-2019/technicalguidance/naming-the-coronavirus-disease(covid-2019)-and-the-virus-that-causes-it 